\title{
Potencial del nuevo marco normativo para el impulso de la rehabilitación y la regeneración urbana en los ámbitos autonómico y local
}

\section{The potential of the new legal framework to promote urban renewal and regeneration at the regional and local levels}

$\underline{\text { J. Rubio de Val }}^{(*)}$

\section{RESUMEN}

El nuevo marco normativo (Ley 8/2013) ofrece posibilidades de intervención sobre el parque de viviendas, a implementar desde los ámbitos autonómico y local. De no desarrollarse en estos ámbitos, se perderá una oportunidad de comprobar los posibles resultados de la ley en un momento económico especialmente necesitado de políticas de estímulo y de inversión en el parque inmobiliario más obsoleto de nuestro país. Desde la experiencia en Zaragoza, se proponen fórmulas de gestión para el impulso de la rehabilitación y la regeneración urbana: apoyo en los primeros pasos del proceso, creación de entes mixtos público-privados y la canalización de ayudas europeas.

Palabras clave: Rehabilitación y regeneración urbana; ámbitos autonómico y local; gestión.

\section{ABSTRACT}

The new legal framework (Act 8/2013) offers intervention possibilities in the housing sector at both the local and regional levels. If not implemented at these levels, a golden opportunity to confirm the possible results of this new law on today's largely obsolete building sector will be missed, especially considering that at this very challenging time stimulating political and investment measures is of vital importance. Examining the experience in Zaragoza, we propose some management formulas to promote refurbishment and urban renewal: support during the very first stages of the process, the creation of mixed (public-private) entities, and the securing of European funding.

Keywords: Refurbishment and urban regeneration; local and regional level; management.

(*) Jefe del Área Rehabilitación Urbana y Proyectos de Innovación Residencial, Sociedad Municipal Zaragoza Vivienda. Zaragoza (España).

Persona de contacto/Corresponding author: jrubio@zaragozavivienda.es (J. Rubio de Val)

Cómo citar este artículo/Citation: Rubio de Val, J. (2015). Potencial del nuevo marco normativo para el impulso de la rehabilitación y la regeneración urbana en los ámbitos autonómico y local. Informes de la Construcción, 67(EXTRA-1): mo23, doi: http://dx.doi.org/10.3989/ic.14.072.

Licencia/License: Salvo indicación contraria, todos los contenidos de la edición electrónica de Informes de la Construcción se distribuyen bajo una licencia de uso y distribución Creative Commons Reconocimiento no Comercial 3.o. España (cc-by-nc). 


\section{PREÁMBULO: BALANCE CRÍTICO DE LA SITUACIÓN}

El 30 de abril de 2010 en el Congreso Sustanaible Building Conference SBMAD10, celebrado en Madrid, sobre «Edificación Sostenible, Revitalización y Rehabilitación de Barrios», iniciaba mi intervención en el mismo, con la siguiente pregunta-declaración:

«Cuáles son las razones por las que todavía, la práctica de la rehabilitación sobre el patrimonio edificado existente, ha sido (sigue siendo) una actividad minoritaria frente a la construcción de nuevos edificios, o que los proyectos más o menos integrados de actuaciones regeneradoras sobre áreas urbanas, sigan siendo experiencias notables pero escasas y casi experimentales, a diferencia de lo que ocurre en la mayoría de los países europeos de nuestro entorno».

Desde entonces, y ya han pasado cuatro años de ello, con cierta machaconería y un punto de provocación y de lamento, introduzco la parte propositiva final de mis charlas, en diferentes foros en los últimos años, con una afirmacióndeseo:

«Se debe pasar en España, definitivamente, de la teoría, o de prácticas experimentales, a la práctica de la rehabilitación generalizada, sistematizada, con criterios urbanísticos y de sostenibilidad del amplio patrimonio edificado existente».

\section{1. ¿Qué está pasando?}

Nos encontramos «atascados» desde hace dos o tres años, en un punto, en el que hay un gran consenso en el diagnóstico (y esto es muy positivo), sobre una situación caracterizada por la necesidad de un cambio de modelo en los usos urbanísticos de nuestro país. Hemos sido capaces de iniciar los primeros pasos en esa nueva dirección (y esto es también positivo, pero no suficiente), pero somos incapaces, al parecer, como sector, de proporcionarnos un marco normativo y económico, que nos permita pasar de los experimentos aislados, a una situación más estable, que atraigan la inversión económica privada y pública a estas tareas.

\section{SÍNTOMAS DE CAMBIO}

El momento actual, no obstante, y a pesar de lo mucho que queda aún por hacer, presenta algunos síntomas positivos. Parece llegada la hora en nuestro país, para este tipo de estrategias y de un cambio de modelo urbano.

Debido, quizás, a diferentes motivos: al hartazgo y las consecuencias producidas por el modelo anterior...; a que el sector está asumiendo la existencia de un déficit de este tipo de obras frente a lo que ocurre en nuestro entorno más próximo (el peso real de la rehabilitación en España está quince puntos por detrás de la media europea, situada en el entorno del $41 \%$ del sector de la construcción, según datos de Euroconstruct de 2013)...; a la comprobación de algunos resultados positivos en actuaciones puntuales de este tipo....; a que el potencial de la rehabilitación residencial con criterios de ahorro energético, en nuestro país es muy alto y sus ventajas medioambientales sociales y económicas son evidentes (como se ha comprobado en otros países, como Alemania, Francia e Inglaterra).

\section{PREAMBLE: CRITICAL EVALUATION OF THE SITUATION}

On 30 April 2010 at the SBMAD1O Sustainable Building Conference, held in Madrid on "Sustainable Building, Revitalization and Neighborhood renovation" my speech began with the following question/statement:

"What are the reasons why cultural heritage refurbishment has been (and still is) a marginal practice compared to the construction of new buildings, and why are projects more or less integrated into urban regeneration interventions still a remarkable and scarce, almost experimental phenomenon, in contrast with many other neighboring European countries?".

Since then four years have passed, and with a bit of insistence, provocation and regret, I introduce the final and prescriptive portion of my talk, given at different forums over the last few years, with a statement/wish:

"In Spain, we most definitely must move beyond theory and experimental practices to widespread, systematized refurbishment practices, in line with urban and sustainable criteria applied to our sizeable wealth of existing building assets".

\subsection{What is going on?}

We have found ourselves "stuck" for two or three years, at a point where there is a great consensus regarding the diagnosis (and this is a very positive thing) identifying the need for a new model governing our country's urban practices. Yet, we have been incapable of implementing this change. We have taken the first steps in this new direction -which is positive, but not enough- but we seem to be incapable, as a sector, of providing an economic and legal framework that allows us to graduate from experiments to the achievement of a more stable situation, able to attract public and private funding for these projects.

\section{SIGNS OF CHANGE}

Even though there is much to be done at this time, and a long road ahead, there are some positive signs out there. It is high time that these strategies and a change in the urban model were introduced in our country.

This is, perhaps, for various reasons: an enormous weariness and the consequences that the previous model generated, the fact that the sector is now acknowledging a lack of these kinds of projects, which are being embraced by our closest neighbors (the real weight of refurbishment in Spain lags 15 points behind the European average, which represents around $41 \%$ of the construction sector, according to the Euroconstruct database in 2013), the confirmation of some positive results from certain projects of this kind, the fact that there is great potential for residential refurbishment, particularly with regards to the enhancement of energy efficiency standards, which in Spain are high, and that the environmental, social and economic advantages of these interventions are evident, as demonstrated in countries like Germany, France and the UK. 
Ya lo adelantaba, con otras palabras, en un anterior artículo en Informes de la Construcción del año 2011 (1):

«Se puede afirmar que hay síntomas positivos de cambio, $y$ actualmente existen dos nuevos "motores" para impulsar la rehabilitación residencial: el gran potencial de ahorro energético que supone y la crisis del sector de vivienda nueva».

Y también, es justo reseñarlo, debido a cierto cambio de tendencia en algunas políticas emprendidas a nivel estatal entre los años 2008 y 2011, inicialmente con unos textos bienintencionados pero algo deslavazados y repartidos en diversos decretos con finalidades muy variadas, lo que las hizo pasar inadvertidas y poco operativas ${ }^{1} \mathrm{u}$ otras como la ambiciosa Ley 2/2011 de Economía Sostenible, que dedicó el capítulo IV del Título II sobre Sostenibilidad medioambiental, a tratar el tema del impulso de la rehabilitación y de la regeneración urbana, en el marco de otras medidas para el impulso de una economía sostenible, baja en carbono y competitiva. Algunas de estas medidas eran muy novedosas, modificando leyes como la de Propiedad Horizontal o la Ley del Suelo, Ley Hipotecaria, etc. Así lo constataba en la página 253 de un artículo anterior (2) al calificar de insuficiente e inadecuado, aunque bien intencionado, el marco legal anterior a la Ley 8/2013.

Y también en la adaptación de normativas autonómicas a la nueva situación, como más adelante tendré ocasión de comentar brevemente, singularmente en el País Vasco, con su ambicioso y bien estructurado Plan Estratégico de Rehabilitación y Regeneración Urbana 2010-2013, retomado en lo sustancial por el Gobierno Vasco actual o antes en Cataluña con su Ley de Barrios del 2004 y el más reciente borrador de Decreto por el que se regula el «plan marco de vivienda y rehabilitación de Andalucía», presentado en noviembre de 2013.

A ello se suman las Modificaciones o nuevas Leyes autonómicas para regular y adaptarlas a la Ley estatal 8/2013 de rehabilitación, regeneración y renovación urbanas en algunas Comunidades Autónomas (CCAA) como Aragón (mayo de 2013) o la más reciente de Castilla y León (mayo de 2014), que también más adelante se referencian.

Son algo más que síntomas de cambio pues revelan la reflexión, el debate técnico, jurídico pero también político, que se traduce en normas y en la puesta a disposición de esas políticas de recursos económicos, siempre escasos, pero significativos de un cambio del modelo imperante hasta hace unos años. Y deben ser bienvenidos, estudiados y copiados, con las necesarias adaptaciones a cada ámbito.

\section{EL IMPULSO DE LAS DIRECTIVAS Y LAS SANCIONES EUROPEAS. EL PAPEL DE LAS CIUDADES EN EL NUEVO PERIODO DE LOS FONDOS ESTRUCTURALES 2014-2020}

Por último, las sucesivas llamadas de atención y amenazas de sanciones llegadas desde Bruselas ${ }^{2}$, sobre los incumplimien-
This was already suggested, in other words, in a previous paper in Informes de la Construcción (1):

"It can be said that there are positive signs of change, and today there exist two new "motors" to drive residential refurbishment: the great energy efficiency potential it entails and the crisis in the new homes sector".

It should also be noted that positive signs include a certain change in the trends of some policies adopted at the state level between 2008 and 2011. Initially these consisted of some wellintentioned but vague texts issued via various decrees with wideranging purposes, which made them go unnoticed, and rendered them barely operative, ${ }^{1}$ and others such as the ambitious Act 2/2011 on the Sustainable Economy, whose Chapter IV, Section II on Environmental Sustainability addressed the promotion of urban renovation and reconfiguration, together with other regulations also intended to foster an economy that is sustainable, competitive and low in carbon emissions. Some of these measures were very innovative, modifying laws such as that on Horizontal Property (or the Land Law), the Mortgage Act, etc. This was noted on page 253 of a previous article (2), which described the previous legal framework of Act 8/2013 as insufficient and inadequate, albeit well-intentioned.

Also promising is the adaptation of regional government regulations to the new situation (as will be briefly discussed below), specifically in the Basque Country, with its ambitious and well-structured 2010-2013 Strategic Action Plan for Urban Renovation and Regeneration, essentially resumed by the current government; the Government of Cataluña's 2004 Neighborhoods Act; and Andalucía's November 2013 Decree regulating its "housing and refurbishment plan".

To all this must be added the modifications and new regional government laws to regulate and adapt them to State Law 8/2013 urban renewal, regeneration and renovation in some regions, such as Aragón (May 2013), or, more recently, Castile \& León (May 2013), also to be mentioned below.

These are more than just symptoms of this change, as they reveal reflection, and a technical, legal and political debate yielding regulations and consequent funding (always scarce, but positive). There are, then, signs that a model that prevailed until a few years ago has seen a shift. And these signs must be welcomed, studied and copied, with the necessary adjustments for each context.

\section{THE PROMOTION OF EUROPEAN DIRECTIVES AND SANTIONS. THE ROLE OF THE CITY IN THIS NEW PERIOD OF STRUTURAL FUNDS, 2014-202O}

Last but not least have been the successive series of wakeup calls and sanction warnings from Brussels ${ }^{2}$ due the

\footnotetext{
${ }^{1}$ Real Decreto ley 6/2010, de 9 de abril, de medidas para el impulso de la recuperación económica y el empleo. Y Disposición Final Primera del Real Decreto-ley 5/2011 de Medidas para el Afloramiento y Control del Empleo Sumergido y fomento de la Rehabilitación de Vivienda, publicado en BOE $n^{0} 108$ de 6 de mayo de 2011.

${ }^{2}$ España aplicó la Directiva 2002/91/CE en lo relativo a certificación de edificios nuevos con el «procedimiento básico para la certificación de eficiencia energética de edificios de nueva construcción», aprobando el RD 47/2007. En noviembre de 2011 la Comisión Europea llevó al Tribunal Europeo de Justicia la inexistencia en España de regulación para la certificación de edificios existentes, y una serie de defectos de aplicación de la Directiva respecto a las inspecciones en caldera.
} 
tos manifiestos del Gobierno español, acerca de la Directiva de Eficiencia Energética de la Edificación, inicialmente aprobada en 2002 (Directiva 2002/91/CE), posteriormente modificada por un texto refundido con incorporaciones aprobadas entre 2008 y 2010 (Directiva 2010/31/UE) y una última e importante modificación (Directiva 2012/27/UE), que modificaba o derogaba otras directivas anteriores y que sentaba las bases para los próximos años, han llevado al Gobierno a transponer esta Directiva, con la aprobación a remolque, de algunos Reales Decretos, aparecidos en la primavera del año pasado $2013^{3}$.

A todo lo anterior pueden añadirse la Estrategia Temática para el Medio Ambiente Urbano, el Marco Europeo de Referencia para la Ciudad Sostenible, o la Declaración de Toledo -aprobada por los Ministros responsables del desarrollo urbano de los 27 Estados miembros de la Unión Europea el 22 de junio de 2010-, de acuerdo con la cual «la batalla principal de la sostenibilidad urbana se ha de jugar precisamente en la consecución de la máxima ecoeficiencia posible en los tejidos urbanos de la ciudad ya consolidada», y en la que se destaca la importancia de la Regeneración Urbana Integrada (RUI) y su potencial estratégico para un desarrollo urbano más inteligente, sostenible y socialmente inclusivo en Europa.

La contrapartida a estas medidas coercitivas, se encuentra en la decidida apuesta de la UE por el fomento y apoyo económico a estas políticas. Ya que varios de los 11 objetivos temáticos propuestos por la UE, en el nuevo periodo 2014-2020 de los Fondos Económicos FEDER y FSE (The European Regional Development Fund -ERDF- and the European Social Fund ESF-), inciden en algunas de las actividades del sector de la vivienda en general y del sector público de vivienda, en particular: fomento de la rehabilitación energética, vivienda en alquiler, reactivación de áreas urbanas degradadas, etc.

La Regeneración Urbana Integrada (RUI) permite abordar varios problemas señalados por la Comisión como prioritarios: alto consumo energético de la edificación, degradación de zonas urbanas, desempleo, envejecimiento y dependencia, segregación social e innovación.

El Reglamento del FEDER (art. 7.4) señala la obligación de dedicar al menos un $5 \%$ del presupuesto FEDER para: «medidas integradas para el desarrollo urbano sostenible, en las que las ciudades, los organismos subregionales o locales responsables de la aplicación de estrategias urbanas sostenibles («autoridades urbanas») serán los encargados de las tareas relacionadas, por lo menos, con la selección de las operaciones».

Sin embargo, esta participación de las ciudades, al menos en el periodo anterior, quedó reducida a las secuelas de los proyectos URBAN. La gestión desde las ciudades, a menos que esto se corrija, está siendo escamoteada en muchos casos, en el caso español, en varias de sus CCAA, al ser éstas la que deciden, al aprobar sus Programas Operativos, si se abre o no ${ }^{4}$ a las ciudades de su ámbito la gestión directa de estos programas integrados ITI (Iniciativas Territoriales Integradas), llevando a una cierta frustración a algunas ciudades con capacidad y
Spanish government's manifest violations of the Building Energy Performance Directive (originally approved in 2002 - Directive 2002/91/CE) and subsequently modified by a consolidated report with some incorporations approved between 2008 and 2010 (Directive 201O/31/UE) a final, important revision coming with Directive 2012/27/ UE, which modified or derogated other previous ones and laid the foundations for the following years, spurring the government to transpose this Directive, with some Royal Decrees finally being approved, though appearing late, in the spring of $2013^{3}$.

Also worthy of mention are the Thematic Strategy on the Urban Environment, the European Legal Framework for the Sustainable City, and the Toledo Declaration-approved by the ministers responsible for the urban development of the 27 EU member states, on 22 June 201O-, according to which: "the main battle for urban sustainability must involve the achievement of the maximum ecoefficiency possible in the fabrics of the already-consolidated city". Underscored was the importance of Integrated Urban Regeneration (IUR) and its strategical potential for more intelligent, socially inclusive and sustainable urban development in Europe.

The counterpoint to these coercive measures is the EU's determined commitment to promote and fund these policies. Several of the 11 thematic objectives established by the EU during the 2014-202O period with ERDF (European Regional Development Fund) and FSE (European Social Fund) funds focus on some general activities of the housing sector, and some in particular: promoting energy renovation, rental housing, the renewal of derelict urban areas, etc.

Integrated Urban Regeneration (IUR) makes it possible to address several problems identified as priorities by the Commission: excessive energy consumption in buildings, derelict urban areas, unemployment, ageing populations, and dependency, segregation and innovation.

The ERDF regulation (Art 7.4) calls for at least $5 \%$ of ERDF funding for: "integrated measures for sustainable urban development, in which cities, subregional or local bodies responsible for the application of sustainable urban strategies ('urban authorities') shall be those charged with the related tasks, at least, with the selection of the operations".

However, this participation by cities, at least in the previous period, was reduced to the aftereffects of the URBAN projects. Management by cities, if not bolstered, is being undercut in many cases. In Spain in particular, in several Comunidades Autónomas (regional governments) it is these which are in charge; when approving their Operational Programs ${ }^{4}$, it is they who decide whether ${ }^{4}$ the direct management of these integrated ITI (Integrated Territorial Initiatives) shall be opened to cities. This is frustrating for some cities,

\footnotetext{
3 Superado ampliamente el plazo de trasposición, se aprobó finalmente el RD 235/2013, de 5 de abril, por el que se aprueba el procedimiento básico para la certificación de la eficiencia energética de los edificios existentes. En diciembre de 2013 se aprueba también una importante modificación del Código Técnico de la Edificación (CTE) en materia de ahorro energético (Documento Básico HE sobre ahorro de energía).

4 Conocemos cómo en el País Vasco ésta posibilidad se ha abierto a las ciudades, mientras que en el caso de Aragón, no se ha permitido.
} 
experiencia de gestión en estos temas. Así lo expresa Michael Parkinson en las conclusiones de un artículo reciente acerca del modo en que se gestionan estos fondos en varios países europeos, y singularmente sobre España (3):

«Elproceso de tomas de decisiones en España sobre los Fondos Estructurales está todavía muy centralizado. Tanto los planteamientosterritoriales comosectoriales delos Fondospodrían verse favorecidos en el futuro... Existe una gran preocupación sobre el hecho de que las regiones podrían tener un papel más visible en los debates y planificación de los Fondos Estructurales, pero no las ciudades. Las ciudades están frustradas por su incapacidad de participar o influir en las decisiones sobre cómo se conformarán y aplicarán los Fondos Estructurales».

Más recientemente el Informe de la Comisión al Parlamento Europeo y al Consejo, sobre respaldo financiero a la eficiencia energética de los edificios, de fecha 18 de abril de 2013 (4), analiza los marcos actuales de financiación y los previstos para los próximos años, para el cumplimiento de la Directiva de Eficiencia Energética (DEE). Hace también un detallado análisis de las barreras existentes y la ausencia de incentivos para su aplicación. Para ello:

«La Comisión está estudiando si, a la vista de las disposiciones de la DEE y de la necesidad de establecer un marco seguro para la concesión de respaldo financiero a la política de eficiencia energética, es necesario modificar las normas en materia de ayudas estatales en relación con dicha política».

Destacar también que en sus conclusiones el documento señala que:

«Si la UE se propone cumplir sus objetivos de eficiencia energética para 2020, así como sus ambiciones de ahorro para 2050, es necesario mejorar el respaldo financiero a la eficiencia energética de los edificios. Para ello es necesario asegurar un cumplimiento del marco normativo vigente, más disponibilidad de financiación y la eliminación de las principales barreras».

Lamentablemente, un grupo de Sociedades Públicas Municipales $^{5}$ de ciudades con experiencia en procesos de rehabilitación de barrios, que hemos constituido una incipiente red por la rehabilitación y regeneración urbanas, apoyados técnicamente por el Área de Rehabilitación y Regeneración Urbana Integrada del Instituto Tecnalia, hemos tenido una mala experiencia muy reciente con las autoridades del Ministerio de Hacienda que elaboraban el Acuerdo de Asociación, con las que mantuvimos una reunión antes de su aprobación del Gobierno Español y comprobar cómo la obligación de fijar un $5 \%$ de los recursos del FEDER asignados a cada Estado miembro para acciones integradas para el desarrollo urbano sostenible, en el que el peso de las políticas de fomento de la rehabilitación deben jugar un papel esencial, como el propio Gobierno español está intentando hacer ( $\sin$ mucho éxito por cierto $^{6}$ ), no se recogen adecuadamente y no se prevé ningún instrumento ni vía para incentivar con ayudas, a la rehabilitación de edificios which possess the capacity and experience to manage these issues. This situation was expressed by Michael Parkinson in the conclusions of a recent article about the way this funding is managed in several European countries, Spain in particular (3):

"The decision making process in Spain regarding the Structural Funds is still very centralized. Both the territorial and sectorial planning of the funds could be favored in the future...There is a great concern about the fact that the regions could have a more visible role when discussing and planning these Structural Funds, but not the cities. The cities are, therefore, frustrated due to their inability to participate or influence decisions regarding how the Structural Funds will he handled and applied".

More recently, the Report of the Commission to the European Parliament and the Council, on economic support for energy efficiency in buildings (18 April, 2013) (4), analyzes the current funding framework, and those envisaged for future years, for compliance with the Energy Efficiency Directive (EED). A detailed analysis is carried out of the existing barriers and the absence of incentives for their application. To this end:

"The Commission is studying whether, in light of the DEE's dispositions, and the need to establish a secure framework for the granting of financial support for energy efficiency policies, it is necessary to modify the regulations pertaining to state funding in relation to said policies".

It should be stressed as well that the report's conclusions state that:

"If the EU aims to meet its energy efficiency goals for 202O, and its savings goals for 2050 , it is necessary to improve financial support for energy-efficient buildings. To this end it is necessary to assure compliance with the current regulatory framework, more available financing, and the elimination of the main barriers".

Unfortunately, a group of Public Municipal Corporations ${ }^{5}$ formed $^{5}$ by cities with experience in local regeneration, with which we had constituted an incipient network for refurbishment and urban regeneration (technically supported by the Integrated Urban Regeneration and Refurbishment Area of the Tecnalia Institute) recently had a negative experience with the authorities at the Tax Ministry, which elaborated the Association Agreement. We held a meeting with them before the Spanish government's confirmation of the obligation to designate $5 \%$ of ERDF funds assigned to each member state for integrated actions for sustainable urban development. In it, policies to boost refurbishment must play an essential role (as the government itself is striving to do, with very little success $\left.{ }^{6}\right)$. Neither does it adequately include or provide for any instrument or alternative to promote, with financial aid, the refurbishment of buildings through

\footnotetext{
5 La Empresa Municipal de la Vivienda y Suelo de Madrid (EMVS), la Sociedad Urbanística de Bilbao S.A. (Surbisa), la Empresa Municipal de la Vivienda de Gijón y la Sociedad Municipal Zaragoza Vivienda.

${ }^{6}$ En los días en que este artículo se escribe han transcurrido más de 14 meses desde que se aprobó el Plan Estatal de Vivienda, sin que se haya destinado ni un euro del mismo a obras de rehabilitación, al no haberse firmado todavía, de manera incomprensible, los acuerdos bilaterales con las CC.AA.
} 
por medio de las Comunidades de Propietarios, con las que ni se había contado.

Por último y quizás lo más relevante ocurrido a mi juicio en este ámbito normativo en los últimos años ha sido la aprobación de la reciente Ley 8/2013, de 26 de junio, de rehabilitación, regeneración y renovación urbanas, objeto ya de numerosos comentarios en los últimos meses y a la que dedico el siguiente apartado.

\section{LEY DE REHABILITACIÓN, REGENERACIÓN Y RENOVACIÓN URBANAS}

La Ley 8/2013, de 26 de junio, de rehabilitación, regeneración y renovación urbanas ( $\mathrm{L}_{3} \mathrm{R}$ ), ha venido, en mi opinión, a tratar de corregir el desequilibrio estructural que en el ordenamiento urbanístico y en el ordenamiento jurídico en general, existía en nuestro país entre la planificación urbanística de nueva ciudad y de nuevos desarrollos, frente a la intervención sobre los tejidos urbanos existentes. Y así parece entenderlo el legislador al expresar en el segundo párrafo de la exposición de motivos de la citada ley esta misma idea junto con otra en la que advierte de la complejidad de gestión que esto conllevará y de las dificultades económicas y financieras del momento, en el siguiente comentario de la exposición de motivos de la ley:

«La tradición urbanística española, como ya reconoció el legislador estatal en la Ley 8/2007, de 28 de mayo, de Suelo, se ha volcado fundamentalmente en la producción de nueva ciudad, descompensando el necesario equilibrio entre dichas actuaciones y aquellas otras que, orientadas hacia los tejidos urbanos existentes, permiten intervenir de manera inteligente en las ciudades, tratando de generar bienestar económico y social y garantizando la calidad de vida a sus habitantes».

Pero la Ley no solo ha llegado para corregir ese tradicional desequilibrio, sino también a intentar crear un nuevo marco normativo que facilite la gestión y coadyuve en la financiación de las actuaciones de los propietarios organizados en torno a las Comunidades de Propietarios y otras figuras de gestión más novedosas, en tanto no exista un desarrollo legal en igual medida que permita sustentar las operaciones de rehabilitación y las de regeneración y renovación urbanas, en las que, además, todavía persisten obstáculos legales que impiden su puesta en práctica o, incluso, su propia viabilidad técnica y económica.

Suelo decir que esta ley en mi opinión no es una ley «intervencionista» en el sentido de que no es una ley que establezca nuevas obligaciones a los propietarios que no estuviesen ya recogidas en anteriores normas y singularmente las que giran, desde la primera ley del suelo española de 1956, en torno al deber de conservación de los edificios y a sus límites, como señala Ángela de la Cruz una de la juristas que mejor la conoce debido a su activa participación en la elaboración de la nueva Ley, en un reciente artículo glosando la L3R (5):

«La nueva L3R no amplía el contenido del deber legal de conservación que ya estaba vigente en España con anterioridad, pero sí regula sus mínimos con carácter uniforme, como corresponde al tratamiento de uno de los deberes exigibles a todos los españoles, en el marco del estatuto jurídico básico de la propiedad del suelo, que compete regular al legislador estatal (art. 149.1.1a CE)». owners' associations, which have not even been taken into consideration.

Perhaps the most relevant aspect of the legal framework over the last few years was the approval of the recent Act $8 / 2013$ of 26 June on urban renewal, regeneration and renovation, featured in numerous comments in recent months, and which I address in the following section.

\section{URBAN RENEWAL, REGENERATION AND RENOVATION ACT}

Act 8/2013 of 26 June on urban renewal, regeneration and renovation $\left(L_{3} R\right)$, in my view, seeks to correct the general structural imbalance in our country's urban planning and legal provisions regarding urban planning for new cities and new developments, as opposed to intervention on existing urban fabrics. This seems to be the government's understanding as well, when it expresses this same idea in the second paragraph of the exposition setting forth the rationale for the aforementioned act, together with another in which it indicates the complex management involved in the matter, and the economic and financial difficulties at the present time, in the following words about the reasons for the act:

"The Spanish urban planning tradition, as recognized by state legislators in Law $8 / 2007$, on Land Use, has been fundamentally based on the production of new cities, to the detriment of a necessary balance between said actions and those others which, aimed at existing urban fabrics, make it possible to act in an intelligent manner in cities, seeking to generate economic and social well-being, and guarantee inhabitants' quality of life".

But the Act has not only come about to redress that traditional imbalance, but also seeks to create a new legal framework which will facilitate management and contribute to the funding of actions carried out by owners, organized into owners' associations, and other more recent management mechanisms, as there exists no equal legal development favoring urban renewal, regeneration and renovation operations, which, in addition, face ongoing legal barriers preventing their implementation, and even their economic and technical viability.

Ioften say that this act, in my opinion, is not "interventionist" in the sense that it is not one that establishes any new obligations for owners that did not already appear in previous legislation, which since the first Spanish Land Use Law of 1956, has revolved around the duty to preserve buildings and their surroundings, as indicated by Ángela de la Cruz, one of the jurists who knows the Act best, due to her active participation in the drafting of the new one. In a recent article commenting on the $L_{3} R$ (5) she wrote:

"The new $L_{3} R$ does not expand on the content of the legal duty of conservation, which was already in place in Spain previously, but it does regulate its minimum standards in a uniform manner, as befits the handling of the one of the duties affecting all Spaniards, in the framework of the basic legal statute of the property law, which it is the function of the state legislators to regulate (Article 149.1.1a EC)”. 
Ni que mucho menos, «obligue» a rehabilitar su edificio a quien no quiere hacerlo, como se ha dicho, con intención de derribar políticamente esta importante iniciativa legislativa, por los mismos o afines, que impulsaron estas mismas ideas, con el gobierno anterior. Otra cosa es el cumplimiento de los estrictos deberes de conservación. Eso solo no se puede entender como rehabilitación edificatoria, que en mi opinión, va algo más allá de la mera conservación o mantenimiento y trata de poner al día el edificio y la vivienda, en materia de accesibilidad, aislamiento térmico, e instalaciones básicas, y que salvo para algunos supuestos en el tema de la accesibilidad, siguen estando, mal que nos pese a algunos, en el ámbito de la actuación voluntaria de las Comunidades de Propietarios.

Esta Ley es compleja, muy novedosa en algunos aspectos y requiera para su implementación (voluntaria también) la complicidad de otras administraciones, como también señala la actual Subdirectora General de Urbanismo de la Dirección General de Arquitectura, Vivienda y Suelo del Ministerio de Fomento, Ángela de la Cruz (5), en el ya mencionado artículo, muy clarificador de los objetivos y contenidos de la Ley y cuya lectura completa recomendamos vivamente.

Sin embargo, sí que creo que es una Ley que facilita notablemente las cosas a quien quiera promover actuaciones de rehabilitación y en especial a las Comunidades de Propietarios organizadas, eliminado algunos obstáculos existentes en legislaciones sectoriales (Ley de Propiedad Horizontal, CTE, etc.) o facilitando la búsqueda de recursos económicos, entre otros, en las modificaciones urbanísticas (Ley del Suelo), sin tantos condicionantes, siempre que se haga en ámbitos previamente delimitados y aprobados por la administraciones competentes y mediante los oportunos instrumentos legales de planeamiento urbanístico, como también destaca la misma autora en el mencionado artículo.

Pero de nada habrá servido el esfuerzo realizado desde el actual Ministerio de Fomento, recogiendo por cierto, con buen criterio en mi opinión, algunos avances ya incluidos en la Ley de Economía Sostenible (Título III capítulo IV, arts. 107 a 111) y en el Real Decreto-Ley 8/2011 (capítulo IV, arts. 17 a 22), de medidas de impulso a la actividad económica, si esta Ley 8/2013 no se implementa desde el ámbito local y singularmente por parte de Ayuntamientos y CCAA haciendo uso de sus competencias correspondientes, sobre la que ya advertía en algún artículo mío reciente (2), ya que de nada serviría el esfuerzo, como señalaba antes, en la buena dirección emprendido desde la Administración General del Estado.

\section{DESDE EL ÁMBITO DE LO LOCAL: ¿CRISIS O CAMBIO DE CICLO?}

Los nuevos escenarios sociales, económicos y medioambientales de nuestras ciudades y núcleos urbanos del medio rural nos deben animar a hacer una lectura nueva y en profundidad del conjunto de la ciudad existente, ya que cuando hay cambios tan significativos y los modelos anteriores no sirven, tanto las distintas áreas de la ciudad, como los propios agentes y habitantes que interactúan en la misma, se van a tener que plantear sus nuevas funciones y sus nuevos papeles en el futuro.

Aunque esta reflexión sobre la ciudad existente hace tiempo que ya ha dado, en la mayor parte de nuestras ciudades y nú-
The law, of course, does not force building renovation by those who do not wish to do so, as had been previously alleged by those interested in politically defeating this important legislative initiative -incidentally, many of these being the same people who promoted the very same ideas under the previous government-. Another issue is compliance with strict preservation duties. In my view these cannot really be interpreted as building refurbishment, which goes far beyond mere preservation or maintenance, and seeks to upgrade buildings and dwellings with regards to accessibility, thermal insulation, and basic facilities. Barring some examples involving accessibility, these upgrades, unfortunately, are still limited to actions to be voluntarily undertaken by owners' associations.

This Act is complex, and very innovative in many aspects, and requires for its implementation (voluntary as well) collaboration by other administrations, as is also pointed out by the current Deputy Assistant Director-General for Urban Planning of the Directorate General of Architecture, Housing and Land (Ministry of Development), Ángela de la Cruz (5). The abovementioned article goes a long way to clarifying the objectives and contents of the Act. We recommend a complete reading of it.

However, I do believe that it is an Act which significantly facilitates affairs for those wishing to promote renovation work, especially for organized owners' associations, eliminating some obstacles existing in sectoral legislation, such the Horizontal Property Act and the Technical Building Code. It also seeks to make it easier to secure economic resources for urban reconfiguration (Land Law) without so many constraints, as long as this is done in a context that is previously defined and approved by the competent administration, and employs the adequate urban planning legal instruments, as is also stated by the author of the aforementioned article.

But efforts made by the Ministry of Development - applying sound criteria in my opinion, some progress already included in the Sustainable Economy Act (Title III, Chapter IV, Articles 107 - 111) and Royal Decree-Law 8/2011 (Chapter IV, Articles 17 - 22) on measures to promote economical activity - will be futile if this Act 8/2013 is not implemented locally and individually by the cities and municipalities themselves, exercising their respective competencies. As I already noted in a previous article (2) the effort will be in vain if not carried out continuing in the right direction undertaken by the General Administration of the State.

\section{THROUGH THE LOCAL PRISM: CRISIS OR NEW CYCLE?}

The new social, economic and environmental scenarios in our cities and rural urban centers must encourage us to carry out a new and thorough interpretation of the existing city as a whole, as whenever there are significant changes, and the previous model cannot be implanted, the different areas of the city and interacting agents and inhabitants themselves must consider new functions and roles for the future.

Even though this line of thinking about the city has already made the jump in most of our cities and urban centers, 
cleos urbanos de todo tamaño, el salto desde los centros históricos a otros territorios de la ciudad, ya que no es posible contemplar solo una parte, sino que es necesario contemplar y estudiar la totalidad, incluso en el ámbito territorial y geográfico más próximo, como vienen reivindicando dos de nuestros mejores urbanistas españoles, Juan Luis de las Rivas y Alfonso Vegara, que lo reflejan muy acertadamente en su libro Territorios Inteligentes (6):

«La reflexión sobre el centro histórico acabará conduciendo a otra más amplia, ya que el rigor analítico y la exigencia de calidad generalizada para el espacio residencial se ampliará a la periferia y al conjunto de la ciudad».

\subsection{Es la hora de algunos cambios: debemos encon- trar respuestas a nuevas preguntas}

Sin embargo, la cuestión, o mejor las cuestiones que se plantean en este nuevo tiempo, son muchas y no siempre son fáciles de contestar, sobre todo porque a veces nos viene a la mente, aquella afirmación, atribuida a Mario Benedetti, sobre que «cuando creíamos conocer todas las respuestas, nos cambiaron la preguntas».

Juli Ponce Sole en un reciente y excelente artículo (7), en el que reflexiona sobre las políticas públicas para afrontar la regeneración urbana de barrios degradados, desde el mundo del derecho, se hace una serie de preguntas al final del mismo, que considero reflejan bien las cuestiones fundamentales a las que debemos de intentar dar respuesta en estos momentos. En ellas se demanda sobre si nuestras organizaciones públicas están preparadas para este nuevo tiempo y estas nuevas demandas sobre la ciudad consolidada.

En primer lugar, estas preguntas, esta reflexión amplia, debe hacerse por los responsables políticos y técnicos (en este orden), sobre el conjunto de la ciudad y del territorio en el que se sitúan, bajo principios de equidad y calidad urbana universales. Puede resultar muy útil a ambos: a técnicos y a políticos, a políticos y a técnicos, el inspirador y ambicioso informe de 2011 de la Dirección General de Política Regional de la UE, titulado «Ciudades del Mañana Retos, visiones y caminos a seguir» (8), que recomendamos. En el informe se constatan las diferentes visiones, desde distintos agentes, sectores de población, etc. que se tienen sobre el futuro de las ciudades. Entre intereses que pueden chocar y que a veces no son fácilmente conciliables, por lo que aconsejan una «visión compartida» y a varias escalas.

La cuestión es lo suficientemente amplia que excede al escaso espacio de un artículo como éste, por lo que nos centraremos en la cuestión de la regeneración urbana de áreas y dentro de éstas en la rehabilitación de edificios, para equilibrar la calidad urbana media de su entorno, para las primeras, y para corregir la obsolescencia y alcanzar la actualización a niveles de confort actuales, en el segundo caso.

\section{2. ¿Qué se puede hacer desde el ámbito autonómico?}

En nuestro país la mayoría de las competencias en materia urbanística están en la esfera de las CCAA, por lo que sin duda, en el momento actual su papel puede servir para ayudar a implementar estas políticas y especialmente la aplicación de la Ley 8/2013. regardless of their size, from historical centers to the other urban areas, it is no longer possible to separate just one part of it. Rather it is necessary to contemplate and study it in a comprehensive manner, in the closest territorial and geographical context, as has been contended by the Spanish urban planners Juan Luis de las Rivas and Alfonso Vegara, who make their point well in their book Territorios Inteligentes (6):

"Reflection on the urban center will end up leading to another broader one, as analytical rigor and the demand for generalized quality for residential spaces will expand to the outskirts, and the city overall".

\subsection{It is time for some changes: we must find new answers to new questions}

However, the questions -or, better yet, the questions asked in our current time- are many and not always easy to answer, especially because sometimes the statement attributed to Mario Benedetti: "just when we thought I knew all the answers, they changed the questions" seems to become true.

Juli Ponce Sole, in a recent and excellent article (7) reflects on public policies to address the urban regeneration of less favored districts, from the legal perspective. He asks himself a set of questions at the end which I believe are the fundamental ones that we should be answering today. Among them, he asks whether our public organizations are equipped for these new times, and the new demands placed upon the consolidated city.

In the first place, these questions should be asked and broad reflections should be made by the responsible politicians and technicians (in this order), about the city as a whole and the territories where they are located, in accordance with principles of equity and universal urban quality. The inspiring and ambitious report (2001) by the European Directorate-General on regional policy, entitled "Cities of tomorrow: challenges, visons, ways forward" (8) may be useful for both experts and politicians. The report contains different visions of the future of cities held by various agents, communities, etc. Some variables may enter into conflict with each other, and at times not be easily reconciled, so a "shared vision" is recommended on several scales.

This question is so broad as to exceed the reduced space available for an article like this one, which is why we will focus on the issue of the renewal of cities, and, inside them, the renovation of buildings; to balance average urban quality in the former, and to correct obsolescence and deliver improvements augmenting comfort levels in the latter.

\subsection{What can regional governments do?}

In our country, most urban planning authority is wielded by the regional governments, or Comunidades Autónomas. Thus, their current role can undoubtedly serve to implement these policies, especially with regards to the application of Act 8/2013. 
Conozco las modificaciones más significativas en relación a la rehabilitación urbana hechas por la Comunidad Autónoma de Aragón, que aprobó la Ley 4/2013, de 23 de mayo (BOA del 6 de junio de 2013), a la que dedica un capítulo IV del Título II (Planeamiento Urbanístico), así como algunos trabajos previos a una posible Modificación del Reglamento de la citada Ley, en materia precisamente de rehabilitación.

Todo ello revela una voluntad clara de alineación con la nueva Ley estatal y los Planes de Vivienda y Rehabilitación, que merecen ser destacados, pues nos consta, en este caso particular, la voluntad de al menos intentar facilitar la labor tanto a particulares como a los Ayuntamientos de todo tipo, que tanto en Aragón, como en otras CCAA son de muy diversos tamaños y capacidades, se encuentran muy desamparados y poco informados de estos temas, más allá de alguna jornada de formación a técnicos, sobre el particular, en el mejor de los casos, a nivel nacional (a través de la FEMP) o en las respectivas CCAA.

También son recientes dos textos legales muy significativos: el proyecto de Ley de «medidas sobre rehabilitación, regeneración y renovación urbana, y sobre sostenibilidad, coordinación y simplificación en materia de urbanismo» en Castilla y León y el borrador de decreto por el que se regula el «plan marco de vivienda y rehabilitación de Andalucía», de muy diferente condición y carácter. El primero, eminentemente urbanístico, hace una relectura completa de la legislación, desarrollando y concretando algunos aspectos no regulados en el texto legal, y el segundo lo convierte en un verdadero Plan de Vivienda Autonómico, definiendo actuaciones y ámbitos objeto de posible subvención, etc. Ambos muy interesantes y significativos del momento y del potencial que la L3R tiene en los ámbitos administrativos autonómicos y locales. Bienvenidos ambos, con todas sus virtudes y limitaciones. Merecen ser estudiados a fondo y copiados por otras CCAA, adaptándolos a sus especificas características.

Si tuviese que resumir en pocas palabras una propuesta de mínimos, pediría a los parlamentos autonómicos y a los municipios en materia normativa (hay otros campos en los que estas entidades autonómicas y locales podrían avanzar de los que intentaremos enunciar algunas ideas más adelante), un sencillo deseo: que se legisle o que se hagan ordenanzas para facilitar las actuaciones de rehabilitación a quien quiera promoverlas, que se eliminen trabas administrativas o de gestión, y que se simplifiquen lo máximo posible los trámites administrativos. Todo ello se podría plantear en la legislación urbanística autonómica destinada a los municipios:

- Revisión sistematizada del planeamiento vigente (singularmente las normas de edificación), a la luz de las posibles actuaciones de rehabilitación, regeneración y renovación urbanas.

- Definición de los tipos actuaciones posibles, adaptadas al lugar y características de la edificación existente.

- Criterios de delimitación y delimitación concreta de algunos ámbitos de rehabilitación edificatoria (continua o discontinua), y de regeneración o renovación urbana.

- Definición y regulación de los instrumentos de gestión o de otro tipo, para llevar a cabo las diferentes actuaciones.

- Revisión y en su caso refundición de los instrumentos vigentes de disciplina (ITEs) a la luz de la actual legislación y del Informe de Evaluación del Edificio (IEE) y de los instrumentos vigentes de estímulo y fomento de la rehabilitación privada (ordenanzas, tasas, etc.).
I am familiar with the most significant modifications related to urban regeneration carried out by the region of Aragon, which approved Act 4/2012 of 23 May (BOA, 6 June, 2013) whose Section II, Chapter IV, (Urban Planning) addresses this matter, as well as other works previous to a possible modification of said law with regards to refurbishment.

All this reveals a clear desire for alignment with the new state law and the Housing and Rehabilitation Plans, which should be underscored, as in this particular case it is clear that they aim to facilitate things for both individuals and city halls of all types, which, both in Aragon and in other regions, are of varying sizes and capacities. They have suffered from neglect and a lack of information, with only a few specific training sessions for technicians and individuals, in the best scenarios, at the national level (through the Spanish Federation of Municipalities and Provinces (FEMP) or the respective regional governments).

There are also two very significant and recent legal reports on the topic: the bill on "urban renewal, regeneration and renovation measures, and on urban-related sustainability, coordination and simplification") in Castile \& Leon, and the draft decree that regulates the Andalusian housing and refurbishment framework quite different in condition and character. The first one, mostly urban, provides a full reexamination of the legislation, developing and specifying some aspects not regulated in the legal text. The second one might be described as a genuine Regional Housing Plan, defining actions and areas eligible for funding, etc. Both are very interesting and notable, suggesting the potential that the $L_{3} R$ has in the regional and local administrative contexts. And they are both welcome, with their virtues and limitations. They are, therefore, worth studying thoroughly, and being implemented by other regions, adapted, of course to each of their characteristics.

A minimal proposal, or a summary of what the regional parliaments and municipalities can do in the regulatory sphere (there are other areas where the regional and local entities could make progress; some of these principles to be mentioned below) would be rooted in the aforementioned desire: to facilitate renovation actions by those wishing to undertake them, removing administrative and management barriers and obstacles, simplifying paperwork, etc. These should be considered as measures to be undertaken in regional urban legislation for municipalities:

- A systematic review of the current legislation (specifically building regulations) regarding possible actions regarding renewal, regeneration and urban reconfiguration.

- The definition of possible intervention typologies, adapted to their context and existing building characteristics.

- Specific delimitation and criteria in some areas of building renovation (continuous or discontinuous) and urban regeneration and renovation.

- The definition and regulation of management and other kinds of instruments required to carry out the interventions.

- Review and, if required, a revision of the disciplinary framework (Technical Inspection of Buildings) in light of the current legislation and Building Evaluation Report (Spain's IEE) and the current instruments to 
Podemos ver cómo estas líneas de propuestas coinciden en lo sustancial con la mayor parte de las modificaciones incorporadas a ambas leyes, en Aragón y Castilla y León. La Modificación de la Ley Urbanística de Aragón antes mencionada define el concepto de las actuaciones de rehabilitación edificatoria, regeneración y renovación urbanas, además de proponer los posibles contenidos, de lo que denomina «programas de rehabilitación urbana» y su relación con el Plan General de Ordenación Urbana, que define en sus artículos 190 ter, y siguientes.

En el caso de la nueva legislación urbanística de Castilla y León, la Ley articula un conjunto de medidas cuyo objetivo común, significativamente plasmado en el título preliminar, es conseguir que las políticas públicas que actúan sobre las ciudades de Castilla y León se orienten de forma coordinada hacia la rehabilitación y la regeneración y renovación urbanas y en ella se concretan más algunos aspectos, en el Título IV, que se añade a la Ley 5/1999, de 8 de abril, de Urbanismo de Castilla y León, que incluirá los artículos 151 a 157, en los que se concretan algunos aspectos: definiciones sobre los tipos de actuación, sujetos intervinientes, ámbitos, criterios y reglas para la planificación de las actuaciones de rehabilitación, regeneración y renovación urbana, etc.

\section{6. ¿QUÉ SE PUEDE HACER DESDE EL ÁMBITO LOCAL? ¿QUIÉN TOMA LA INICIATIVA: PROPIETARIOS, ADMINISTRACIONES?}

¿Quién debe tomar la iniciativa, en el momento actual, en ausencia de una «cultura» de la participación proactiva por parte de las Comunidades de Propietarios, más acostumbradas a la cultura de la subvención? Y los Ayuntamientos ċdeben esperar a que los ciudadanos tomen la iniciativa, o por el contrario deben apoyar y estimular los primeros pasos de los procesos de rehabilitación y regeneración urbanas?

La L3R, en su artículo 9 de hecho otorga a ambos, administraciones y propietarios, la posibilidad de tomar la iniciativa:

«La iniciativa para proponer la ordenación de las actuaciones de rehabilitación edificatoria y las de regeneración y renovación urbanas, podrá partir de las Administraciones Públicas, las entidades públicas adscritas o dependientes de las mismas y los propietarios...».

De manera práctica, y desde la perspectiva de la reciente experiencia de gestión en los últimos 10 años con Comunidades de Propietarios, en los 21 Conjuntos Urbanos estudiados en Zaragoza (9), la respuesta a la pregunta que antes nos hacíamos, sobre quién o quiénes deben tomar la iniciativa: ¿̇administración ?, ¿̇propietarios?, creo que tiene una respuesta en una doble dirección.

Se podría comparar la posible delimitación de determinados ámbitos, con la función de las Ordenes Municipales de Ejecución, pero a escala más grande y sin el carácter coercitivo de aquellas. En cierto modo, se trataría de recordar, de informar en definitiva, a un grupo más amplio de propietarios, sobre la necesidad de acometer reformas en conjuntos edificados, que por su edad de construcción, han quedado obsoletos por carecer de manera generalizada de condiciones mínimas de accesibilidad, o de la inadecuación de instalaciones básicas (agua, saneamiento, alumbrado, electricidad, telecomunicaciones) o de carecer de unas adecuadas condiciones de aislamiento térmico, que les hace consumir en exceso energía y gastar innecesariamente. También serviría para comunicarles, que de aprobarse esa stimulate and promote private renovation (ordinances, fees, etc.)

We can perceive how these lines of work converge, essentially matching most of the amendments incorporated in both acts, in Aragon and Castile \& Leon. The modification of the aforementioned Urban Law defines the concept of urban renewal, regeneration and reconfiguration in addition to suggesting potential new contents (dubbed "urban renovation programs") and their relationship to the General Urban Development Plan, specifically in Article 190 and following.

In the case of the new urban legislation in Castile \& Leon, the plan provides a set of measures with a common objective (stated in the preliminary title): to succeed in orienting the public policies of the cities of Castile \& Leon towards coordinated urban renewal, regeneration and reconfiguration efforts. This plan also features other aspects, such as definitions of intervention typologies, contexts, criteria and regulations for the planning of actions involving renovation, regeneration, urban reconfiguration, etc.

\section{WHAT CAN BE DONE AT THE LOCAL LEVEL? WHO TAKES THE INITIATIVE: OWNERS, GOVERNMENT AUTHORITIES?}

Who ought to take the initiative at this time, given the absence of a "culture" of proactive participation by the owners' associations, more accustomed to subsidies? And city halls: should they expect the citizens to take the initiative or, on the contrary, support and stimulate first steps towards urban renovation and reconfiguration processes?

In fact, the $L_{3} R$, in Article 9, invites both government authorities and property owners to take the initiative:

"The initiative to propose the undertaking of building restoration actions, and urban regeneration and renovation, may be taken by the Public Administrations, attached or dependent public entities, or owners..."

In a practical way, and from the perspective of recent management experiences over the last 10 years with owners' associations, in the 21 Urban Ensembles studied in Zaragoza (9), the answer to the question posed above about who must take the initiative (the government? owners?), I believe deserves a two-fold answer.

The possible definition or demarcation of certain areas could be compared with the function of the Municipal Execution Orders, but on a larger scale and without their coercive character. In some ways the idea would be to remind or inform a wider group of owners about the need for comprehensive refurbishment in sets of buildings that, due to their age, are obsolete, lacking minimum accessibility conditions, or having inadequate basic facilities (water, sanitation, lighting, electricity, telecommunications). They usually lack, in addition, the minimal thermal insulation required, causing them to overconsume energy and waste money. It would also be advisable to inform them that, if approved, this definition would bring with it economic benefits in the form of 
delimitación, ello conllevaría algunos beneficios económicos en forma de subvenciones a fondo perdido, de los Planes Estatales, Autonómicos y Municipales de fomento de la rehabilitación o incluso, mediante planes especiales de reforma, la posibilidad de obtener incrementos de edificabilidad o mayores facilidades para la instalación de ascensores sobre suelos públicos, etc.

Y todo ello, a pesar del mandato genérico que la Ley 8/2013 indica en su artículo 9.2 a las «administraciones públicas» sin determinar cuál de ellas debe hacerlo, para intervenir «...cuando existan situaciones de insuficiencia o degradación de los requisitos básicos de funcionalidad, seguridad y habitabilidad de las edificaciones; obsolescencia o vulnerabilidad de barrios, de ámbitos, o de conjuntos urbanos homogéneos; o situaciones graves de pobreza energética. Serán prioritarias, en tales casos, las medidas que procedan para eliminar situaciones de infravivienda...».

La administración municipal, en mi opinión, no va a tomar decisiones, por ejemplo delimitando ámbitos de rehabilitación (continua o discontinua) o de regeneración urbana, sin que previamente exista una demanda, al menos incipiente y mínimamente organizada por parte de los propietarios. Ningún Ayuntamiento va a asumir el riesgo de legislar en el vacío o de que una delimitación de estas características, al amparo de la nueva L3R o de las leyes autonómicas que las desarrollen o concreten, o en el marco del Plan Estatal 2013-2016, non natus, que sea interpretada por los propietarios del área afectada como una imposición para que procedan a rehabilitar sus edificios. Este procedimiento así planteado, no tendría posibilidades de prosperar, en mi opinión. Solo tendrían sentido estas delimitaciones si éstas tuvieran por objetivo el de concentrar en ellos la acción pública coordinada (Ayuntamientos, Comunidad Autónoma y $\mathrm{M}^{\mathrm{O}}$ de Fomento): la información, el apoyo administrativo y las ayudas económicas (subvenciones, financiación cualificada, exenciones de tasas locales, etc.) de los respectivos planes o programas:

Surgen, de nuevo, otras preguntas: ¿Pero acaso no conocen los propietarios el estado de sus casas? ¿Qué se gana con recordárselo..., sin más? Y por otro lado, ¿̇por qué dar ayudas públicas en unos lugares y no en otros?, quizás con características similares. Acaso en estos tiempos de mínimos, por no decir escasísimos recursos públicos para estas materias, ¿̇la acción pública puede llegar a todos los barrios obsoletos, vulnerables, que tenemos en nuestro país? Primera posibilidad: intentar objetivar estas carencias por medio de indicadores iguales para todas las áreas vulnerables o con carencias residenciales generalizadas ${ }^{7}$, con el fin de seleccionar y actuar en función de las posibilidades presupuestarias en unos antes que en otros, o planificar estas inversiones en el tiempo. Segunda posibilidad, inducida por la propia Ley General de Subvenciones 38/2003: realizar procedimientos de concurrencia pública.

El término vulnerabilidad aplicado a áreas urbanas, y el propio análisis de las mismas, bajo este prisma social, económico y residencial ha quedado definido en un estudio sobre barrios grants as part of state, regional and municipal plans for the promotion of renovation, or even, through special refurbishment plans, the possibility of expanded building opportunities, or assistance to install elevators on public grounds, etc.

The generic mandate that Act 8/2013 delivers in its Article 9.2 to "public administrations" fails to specify which one of them must carry out the interventions "...when there are situations of insufficiency, or the degradation of buildings' basic functionality, safety and habitability requirements; the obsolescence or vulnerability of districts, of areas, of homogeneous urban ensembles; or serious situations of energy insufficiency. In these cases priority shall be given to the appropriate measures to eliminate situations of substandard housing...”

Municipal governments, in my view, are not going to make decisions concerning the definition, for instance, of (continuous or discontinuous) renovation or urban reconfiguration areas, without a pre- existing demand to do so, albeit incipient and somewhat organized by the owners. No city hall would assume the risk of legislating in a void, or risk a definition of these characteristics (under the new LR3, or regional government laws that enact it, or in the accord with the 2013-2016 State Plan) being interpreted by the users of the affected area as an imposition requiring the renovation of their buildings. This procedure, planned as such, would be doomed to failure, in my view. These definitions would only make sense if they were aimed at coordinated public action (city halls, regional governments and the Ministry of Development), informing the parties and providing them with administrative support and economic aid (grants, qualified funding, local tax exemptions, etc.).

Other questions are once again raised: Do not the owners perceive the status of their dwellings? Is there any point in reminding them? And why provide public funding in some places and not in others that may feature similar characteristics? During these tough times, when public resources are scant for these kind of issues, can public action reach all the obsolete and vulnerable districts that we have in our country? A first option: seek to gauge these shortcoming using the same indicators for all the vulnerable areas, or those with widespread residential flaws ${ }^{7}$, in order to select or act first on one or the other depending on budgetary possibilities, planning these investments in advance. A second option, in accord with the General Law on Subsidies 38/20o3: carry out public participation procedures.

The term "vulnerability," applied to urban areas, and their analysis, through this social, economic and residential prism, has been defined in a study of vulnerable districts

\footnotetext{
7 Esta metodología que cruza datos físicos y datos socioeconómicos en áreas territoriales concretas, ha sido ampliamente estudiada y desarrollada, desde hace años, de manera pionera, por el profesor y arquitecto Agustín Hernández Aja y los equipos de investigación que ha dirigido, sobre la ciudad de Madrid (2007), sobre todo el territorio nacional (1991, 2001 y 2012), o más recientemente colaborando en la elaboración del Mapa de barrios vulnerables del País Vasco (2012). En este último, con la participación de Tecnalia, se evaluaron unos 60 indicadores, de los que finalmente se redujeron a los diez más significativos (tres de carácter socioeconómico y siete de carácter más físico y urbanístico). El actual Ministerio de Fomento dispone de una buena información sobre áreas vulnerables en España en su página web: http://www. fomento.gob.es/MFOM/LANG_CASTELLANO/_ESPECIALES/SIU/OBSERVATORIO/Analisis_urba_Barrios_Vulnerables/en base a estudios de Agustín Hernández Aja, que también colabora en este monográfico.
} 
vulnerables (10) en el que se hace una distinción entre «área vulnerable» 0 «área problema», muy interesante a mi juicio:

«Así, mientras el término vulnerable indica la necesidad de acciones integrales sobre un área, el término problema permitiría colegir que la solución a éste, podría pasar simplemente por el desarrollo y ampliación de las políticas sectoriales al uso».

\section{7. ¿ESTÁ PREPARADO NUESTRO ORDENAMIENTO JURÍDICO, EN MATERIA URBANÍSTICA, DE PROPIEDAD HORIZONTAL, HIPOTECARIA, FISCAL ETC., PARA ESTAS NUEVAS ACTUACIONES, A PESAR DE LOS AVANCES DE LA NUEVA LEY 8/2013?}

Del otro lado, la iniciativa de los propietarios, delegada en el mejor de los casos en el administrador de fincas, cuando lo hay, lo que no es frecuente en la mayoría de los barrios necesitados de estas intervenciones, hasta ahora sin hábito alguno de agruparse y con limitaciones para hacerlo «organizados» bajo la forma de algún tipo de agrupación de Comunidades de Propietarios. Esta posibilidad se encuentra además muy mermada con la actual Ley de Propiedad Horizontal (LPH), para conformar agrupaciones $\mathrm{u}$ otras formas organizativas o fórmulas de cooperación y coordinación para participar en la ejecución de las que prevé la LR3, en su artículo 15.1, como las denominadas «asociaciones administrativas».

La LPH solo deja a la figura de la Mancomunidad de Comunidades o la creación de una nueva Comunidad de Propietarios esta posibilidad, según su artículo 24. En el caso de la figura de la Mancomunidad, los poderes de ésta se limitan a «los elementos inmobiliarios, viales, instalaciones y servicios comunes», pero sin embargo, el órgano de gobierno de ésta «no podrá menoscabar en ningún caso las facultades que corresponden a los órganos de gobierno de las comunidades de propietarios integradas en la agrupación de comunidades». Lo que en la práctica, en actuaciones de rehabilitación de varias Comunidades (a veces integrantes de un mismo edificio) la limita mucho y convierte a cada Comunidad, en una verdadera «república independiente de mi escalera», parafraseando a una publicidad muy conocida, que apela al individualismo español al invocar el sancta sanctorum de la vivienda como la «república independiente de mi casa».

Las significativas modificaciones introducidas por la L3R en la Ley de Propiedad Horizontal (LPH), singularmente en materia de mayorías o para facilitar la accesibilidad universal, o para aumentar su capacidad de gestión, etc., aun siendo muy positivas, no son suficientes a mi juicio. Esta Ley del año 1960, con apenas algunas pequeñas modificaciones puntuales, debería ser revisada a fondo, en un contexto político, económico, social y medioambiental, bien diferente al que había en aquellos años.

Creo sinceramente que debe cambiar en nuestro país el modo generalizado de gestionar el patrimonio residencial. En ausencia de una legislación actualizada, que regule las relaciones entre propietarios y las de éstos con sus convecinos y con la propia administración, debe renovarse profundamente el modo como se viene haciendo en la mayor parte de nuestros pueblos y ciudades.

La gestión actual, basada mayoritariamente por el propietario no profesional, en la cultura de la «reparación» cuando ya no queda otro remedio, en lugar de en la prevención y manteni-
(10) in which a distinction is made between a "vulnerable area" and a "problem area" -very interestingly, in my view-:

"Thus, while the term 'vulnerable' indicates the need for comprehensive actions on an area, the term 'problem' would make it possible to deduce that the solution could lie simply in the development and expansion of standard sector policies".

\section{IS OUR LEGAL SYSTEM READY, IN THE FIELDS OF URBAN DEVELOPMENT, HORIZONTAL PROPERTY, MORTGAGES, FISCAL, ETC. FOR THESE NEW PROJECTS, DESPITE THE PROGRESS ACHIEVED WITH THE NEW ACT 8/2013?}

Initiatives by owners are delegated, in the best scenarios, to property administrators, when they even exist which is not often in most of the districts in need of these projects-. Until now they have not been in the habit of organizing in this way, and face limitations to do so set up in the form of some kind of owners' association. Moreover, this possibility has also been seriously undermined by the current Horizontal Property Act (LPH) which hinders the formation of groups or other organizations, cooperatives and coordinated entities that might participate in the execution of what the $L_{3} R$ stipulates; its Article 15.1 refers to them as "administrative associations".

The LPH only assigns this possibility to the mancomunidad de comunidades, or the creation of a new owners' association, in accordance with Article 24. In the case of the mancomunidad, its powers are limited to "real estate, roads, infrastructures and common service elements." However, its governance body "shall not be able to subvert, in any case, the purviews of the owners' associations forming the mancomunidad". In practice, when dealing with renovation projects spanning several associations, this gives rise to a genuine "independent republic of my staircase" dynamic, to borrow from a very well- known advertising campaign, which appeals to Spanish individualism by referring to the sancta sanctorum of one's dwelling as the "independent republic of my home".

The significant amendments introduced by the $L_{3} R$ in the Horizontal Property Act (LPH), with regards to majorities, or to facilitate universal accessibility, or to expand management capacity, etc., though very positive, in my view, are not enough. This Act of 196o, save for a few exceptions, should be thoroughly overhauled, in a political, economic, social and environmental context very different from that existing during those years.

I honestly believe that our country must change the way it manages residential patrimony in general. In the absence of updated legislation, able to regulate the relationship between owners and the government, the way things are carried out in most of our villages and cities must be thoroughly revised.

Current management is conducted mostly by nonprofessional owners, in a culture of "repairs" when there is no other option, instead of preventive asset maintenance and 
miento activos y en todo caso en una gestión «inteligente», en la que se prime el mayor valor del edificio y los menores costes de uso y mantenimiento. Esta gestión, referenciada en la figura del administrador de fincas en solitario, debe mejorar y cambiar. Ya hay movimientos en las grandes ciudades de concentración de estos profesionales, que al aumentar el número de viviendas gestionadas les permite ofertar unos servicios profesionales más complejos (fiscales, subvenciones, técnicos, etc.) con costes asumibles, pero sigue primando una gestión a la «defensiva» de los inmuebles, con perfiles muy conservadores y con poca innovación en sus métodos.

\section{8. ¿ES CONVENIENTE ESTIMULAR LA DEMANDA DE ESTE TIPO DE ACTUACIONES, AUN NO TENIENDO BIEN RESUELTA LA OFERTA DE SOLUCIONES DE GESTIÓN, ECONÓMICO- FINANCIERAS?}

Dejo para el final esta última pregunta que no dejo de hacerme en privado y en público en los últimos meses. Aun suponiendo, que es mucho suponer, que hubiese muchos propietarios organizados que tuviesen esa inquietud y una demanda asumida mayoritariamente por la mayoría de integrantes de las Comunidades de Propietarios de nuestros edificios más obsoletos, a día de hoy es difícil disponer de todos los instrumentos urbanísticos, financieros y de gestión resueltos, para satisfacerla. Ni por parte de la iniciativa privada, ni de la pública. ¿Debe por tanto estimularse esta potencial demanda? Lo que de manera indirecta se está haciendo, en momentos de grave crisis profesional, por las entidades profesionales y empresariales, y también por las administraciones públicas, que en abundantes encuentros y jornadas de todo tipo, concluyen inevitablemente en la oportunidad que ofrecen estas políticas de incentivo a la rehabilitación edificatoria, con un acento en los aspectos energéticos de las mismas, para dinamizar la actividad económica, generar empleo, etc.

Y sin embargo, estos instrumentos, a mi juicio no están listos aún. Ni los Ayuntamientos en su conjunto, ni siquiera los de las ciudades medias o grandes, disponen de información sistematizada, que cruce datos sobre el estado del parque edificado con la situación socioeconómica y de propiedad del mismo, ni los mecanismos de gestión están preparados para actuar de forma inmediata, salvo honrosas excepciones. Sirvan las siguientes reflexiones hechas por el representante de Santiago de Compostela, Fernando García Tobio en su informe al grupo de trabajo constituido por la FEMP y el Ministerio de Fomento para implementar el nuevo marco normativo en el ámbito local ${ }^{8}$, en las que constata como:

«La atención prestada a la ciudad consolidada descansa hasta el momento presente en la idea de que se trata de un espacio ya acabado, en el que solo caben algunas actuaciones parciales de reforma o rehabilitación y las exigidas por el mantenimiento de los edificios.

Esta forma de concebir la función urbanística municipal debe de cambiar de forma radical. La ciudad consolidada no es un espacio cerrado y acabado, sino un espacio vivo, susceptible de transformaciones que mejoren las condiciones de vida de smart management. Value is assigned to the building itself, while skimping on maintenance costs. This management, represented by "lone administrators" must improve and change. There are already movements to do this in the big cities, calling for changes with regards to these professionals, as when the number of dwellings managed increases, they can offer a greater number of more complex professional services (fiscal, funding, technical, etc.) at affordable costs. But there still prevails a "defensive" management of real estate assets, with very conservative patterns and little innovation in methods.

\section{IS IT ADVISIBLE TO STIMULATE THE DEMAND FOR THIS KIND OF INTERVENTION, WITHOUT HAVING RESOLVED THE ECONOMIC-FINANCIAL AND MANAGEMENT ISSUES?}

I have left this last question for last, which I have not been able to stop asking myself in private and in public in the recent months. Even assuming -though this may be a stretch- that there were many organized owners with these concerns, and demand existed amongst majorities of the owners' associations of our most obsolete buildings, today it is difficult to access the urban, financial and management instruments provided to satisfy that demand, whether via private or public initiatives. Should this potential demand, then, be stimulated? This, in an indirect way, is being done, during times of serious professional crisis, by professional and business entities, as well as by the public administrations. The latter have inevitably concluded, at meetings and conferences of every kind, that policies providing incentives for building renovation represent a real opportunity, emphasizing improvements in energy efficiency, their capacity to stimulate economic activity, generate employment, etc.

And yet, these instruments, in my view, are still unavailable. City governments, in general, do not have at their disposal systematized information for the cross-matching of data about the state of buildings and about socio-economic situations and properties. With only a few exceptions, nor do they have management mechanisms installed to act in an immediate way. Relevant in this regard are statements made by the representative of Santiago de Compostela, Fernando García Tobio, in his report to the work force constituted by the FEMP and the Ministry of Development to implement the new legal framework locally ${ }^{8}$, when he described how:

"The attention given to the consolidated city rests, at present, on the idea that it is an already complete space which can only accommodate a few partial reform and refurbishment actions, and those demanded for the maintenance of buildings.

This way of understanding municipal urban functions must radically change. The consolidated city is not a closed and finished space, but rather a living one, open to transformations which improve their inhabitants' living

\footnotetext{
8 Por iniciativa de la FEMP y del Ministerio de Fomento se constituyó en los últimos meses de 2013 un grupo de trabajo con algunas ciudades especialmente inquietas y con experiencia en estos temas, como Vitoria, Santiago de Compostela, Madrid, Barcelona, Valencia y Zaragoza, para implementar el nuevo marco normativo en el ámbito local y recibir sugerencias.
} 
sus habitantes. Los Ayuntamientos deben de erigirse en los protagonistas de dichas transformaciones, para lo que es imprescindible que-además de las medidas de carácter normativo-adapten la organización de sus servicios urbanísticos a la nueva realidad, para que sean capaces de asumir la iniciativa en las tareas que se señalan en la ley 8/2013».

\section{LA FINANCIACIÓN NO RESUELTA DE ESTAS ACTUACIONES DE REHABILITACIÓN EDIFICATORIA}

Dejo para el final el importantísimo tema de la financiación de las actuaciones de rehabilitación edificatoria por parte de las Comunidades de Propietarios, que como decíamos antes siguen identificando obras de mejora y de rehabilitación con la existencia de subvenciones públicas a fondo perdido, eludiendo o minimizando la importancia económica de otras consideraciones de tipo fiscal (deducciones en el IRPF por inversión en obras de rehabilitación, IVA reducido del 10\%), la revalorización real del inmueble a efectos de venta y de alquiler por las mejoras energéticas y estéticas introducidas, o los menores costes energéticos en el uso cotidiano y la consiguiente amortización a medio o largo plazo de las inversiones realizables.

La sola financiación basada en las subvenciones públicas, muy disminuidas en la actualidad y que en el mejor de los casos puede llegar a costear un 20-25\% del coste total (si el Plan Estatal con la colaboración de las CCAA y Ayuntamientos, o el lamentablemente inadecuado y fallido ${ }^{9}$ Plan PAREER del IDAE, pudiesen atender la demanda total) y en los recursos privados de los propietarios, no resulta viable en buena parte de los ámbitos de posible actuación, como son los polígonos de los años 50-60 o en los barrios consolidados hasta el año 1980 y menos aún en los actuales momentos de crisis, en los que la poca capacidad de ahorro de los propietarios, no considera prioritarios estos temas, frente a otros como son las eventuales consecuencias del paro, EREs, disminución de ayudas a la dependencia, etc.

Para paliar este desfase entre los costes y la suma de las subvenciones más el posible ahorro previo de los propietarios, debe acudirse necesariamente a la financiación externa y aquí es donde surge el problema principal. Para la renovación de instalaciones (calderas fundamentalmente), cuya amortización es más corta (3 a 5 años), aunque los niveles de ahorro energético sean más bajos (en torno al 10-15\%), sí que hay oferta, a través de Empresas de Servicios Energéticos (ESEs), que adelantan el coste de la instalación nueva, más eficiente y con combustibles distintos (generalmente sustituyen fuel por gas como combustible, o en algunos casos, los menos, por biomasa), generalmente vinculados a los que ellas mismas comercializan (Endesa, Gas Natural, etc.), a cambio de la gestión energética a cargo de ellas en esos años.

Pero, sin embargo, para la mejora de la envolvente (cubierta, fachadas, ventanas, medianiles, etc.) cuyos ahorros teóricos son mucho más altos (entre el 50-60\%) que debería ser el obje- conditions. Cities should establish themselves as the main forces driving this transformation, for which it is essential that - in addition to regulatory measures - they adapt the organization of their urban services to the new reality, so that they are capable of taking the initiative with respect to the tasks indicated in Law 8 /2013".

\section{THE UNRESOLVED ISSUE OF FUNDING FOR THESE BUILDING RENOVATION PROJECTS}

Finally, there is the important topic of funding for renovation interventions undertaken by owners' associations. As we stated before, these associations continue to identify upgrading and renovation projects with the existence of public grants, overlooking or undervaluing the economic importance of other fiscal considerations: personal income tax deductions when investing in renovation projects, sales tax reductions to $10 \%$, the real increase in value of the real state asset with a view to selling or renting after energy-efficiency and aesthetic upgrades have been made; the reduced energy costs of daily use and the consequent amortization, in the medium and long term, offeasible investments.

Funding has largely been based only on public subsidies, currently very limited, and which in the best case scenarios can only cover $20-25 \%$ of the total amount (if the State Plan, with the collaboration of the regional governments and city halls, or the sadly inadequate and unsuccesful ${ }^{9}$ PAREER Plan, from the IDAE, could satisfy total demand) and on the private resources of owners, which are generally not sufficient for potential projects; for instance, in residential ensembles built in the 50s - 6os or districts consolidated until the year 1980 . And even less in the current context of economic crisis, in which owners' saving capacities are limited. But this has not been considered a priority in this context in comparison to the consequences of unemployment, EREs (Workforce Reduction Plans), decreased aid to the dependent, etc.

In order to correct this discrepancy between cost and the sum of subsidies plus owners' previous savings, it is necessary to turn to external funding and this is where when the main problem emerges. There is currently supply for the renovation of infrastructures (mainly boilers/ water heaters) whose amortization is shorter (3 to 5 years), though levels of energy savings are lower (from 10 $15 \%)$, there is supply available through the Energy Service Companies (ESEs), which finance the new technology, which is more efficient and uses different fuels (generally operating on gas, or, in a very few cases, biomass). The producers of fuels are generally linked to the companies selling the technologies using them (Endesa, Gas Natural, etc.) such that it behooves them to provide this service in exchange for the future provisioning of energy services.

The upgrading of buildings' more basic structures (roof, façade, windows, walls, etc.) where savings are,

\footnotetext{
9 El Programa de Ayudas para la Rehabilitación Energética de Edificios existentes del sector Residencial (uso vivienda y hotelero) PAREER, promovido por el Instituto para la Diversificación y Ahorro de la Energía (IDAE), y dotado con 125 millones de euros, no está siendo efectivo. Tan solo 6 Comunidades de Propietarios han solicitado ayudas, desde que se inició el mismo, en Septiembre de 2013, y ninguna de ellas ha podido cumplir los imposibles e inadecuados requisitos exigidos (aval o seguro de caución; escrituras de todos los propietarios, etc.), según información de los responsables del Instituto. Para más incongruencia, las ayudas de este Plan son incompatibles con cualquier otra ayuda pública, para el mismo fin.

Para más información: http://www.idae.es/index.php/id.745/relmenu.409/mod.pags/mem.detalle
} 
tivo a apoyar, no hay financiación ni de las ESEs, cada vez más vinculadas a las grandes empresas energéticas, ni de la banca privada, ni de la banca pública (las entidades rescatadas y que actualmente son públicas), ni el ICO, que en teoría sí tiene alguna línea dedicada a ello, pero que en la práctica al ser gestionadas por la banca comercial, ésta es muy reacia a dar créditos a las Comunidades de Propietarios y todavía menos a hacerlo a plazos largos de 10-15 años. Y sin esta financiación a plazos más largos, única asumible por las Comunidades de Propietarios, en mi opinión, ampliamente compartida en el sector, es imposible pensar en un despegue definitivo de este sector de actividad, del que tan necesitado está nuestro país, por varias razones (empleo, dependencia energética, innovación, etc.).

Entendemos y comprendemos las razones que plantean las pocas entidades financieras que han dado créditos para estas finalidades y los propios Administradores de Fincas, y ello a pesar de que las Comunidades de Propietarios gozan de fama de ser buenas pagadoras, por la dificultad de establecer suficientes garantías a los posibles prestadores de recursos económicos, que los hay, al no tener entidad jurídica, o peor aún, no disponer de otros inmuebles, ni posibles avalistas, que los propios propietarios a título individual, lo que a la larga resulta inviable en la práctica.

Por ello y aunque la L3R plantea algunas posibles soluciones que pueden paliar esta dificultad fundamental, en la búsqueda de las economías de escala, en las posibles fuentes alternativas que pudiesen proceder de aprovechamientos lucrativos, explotación de inmuebles, etc. situados en los ámbitos correspondientes, liberándolos de determinadas servidumbres, bajo el régimen de equidistribución de beneficios y cargas, que se recogerán en una Memoria de Viabilidad (artículo 11 L3R) de los programas o proyectos. $Y$ finalmente, con medidas que aumentan la mayor capacidad de gestión de posibles sujetos legitimados para actuar (artículos 15 a 17 de la mencionada L3R), todas ellas muy positivas, pero que tardarán en ser implementadas. Sin los adecuados instrumentos o vehículos financieros, a buscar y encontrar, que antes reclamaba, no será posible, como ya decía antes, el despegue definitivo de este sector de actividad.

\section{EPÍLOGO: TENEMOS LA OPORTUNIDAD DE CAMBIAR LAS COSAS, HAY QUE INSISTIR, BUSCAR Y ENCONTRAR}

El momento actual y a pesar de lo mucho que queda aún por hacer, presenta algunos síntomas positivos. Parece llegada la hora en nuestro país para este tipo de estrategias y de un cambio de modelo urbano. Las sucesivas llamadas de atención de la UE a nuestro país por el retraso en la transposición de algunas medidas relacionadas con la mejora de la eficiencia energética en el sector de la edificación han estimulado la aprobación de algunas medidas favorecedoras de la rehabilitación de edificios, y ello a pesar del escaso o nulo papel que las autoridades españolas que van a gestionar los Fondos Estructurales (Ministerio de Hacienda y CCAA) otorgan a las ciudades en la gestión de las mismas, lo que debiera corregirse urgentemente para este nuevo periodo 2014-2020.

La Regeneración Urbana Integrada (RUI) es una magnífica oportunidad de reconducir el modelo urbanístico anterior en términos de equidad para todos los habitantes de nuestras ciudades y núcleos urbanos, al tiempo que puede coadyuvar muy eficazmente a la urgente reactivación económica de España, ya que permite abordar varios problemas señalados por la Comisión Europea como prioritarios: alto consumo energético de theoretically, far superior (50-60\%) should be the target pursued. But there is no funding; not from the ESEs, more and more associated with the big energy companies; or from private banking, or from public banking (bailedout entities and that are currently public) or from the ICO (which, in theory, does have a line of work dedicated to this, but in practice, as it is managed by commercial banking, is very reluctant to grant owners associations credit, and even less to do this via long-term installments of up to 10-15 years). Without this long-term funding, only assumable by the owners' associations, in my view (and one widely held in the sector) it is impossible to expect a decisive takeoff of this much-needed activity sector in our country (for various reasons; energy dependency, innovation, etc.)

We understand and comprehend the explanations offered by the few financial entities that have extended credit to this end, and the property owners themselves, even though the owners' associations have a good reputation for paying. It is difficult to offer sufficient guarantees to potential lenders when receivers are not legal entities or, even worse, lack backers or collateral, which renders the transaction nonviable.

The LR3 does include some possible solutions that could remedy this fundamental difficulty: the search for economies of scale, possible alternative sources coming from profitable uses, realestate exploitation, etc. located in the corresponding contexts of the programs or projects, freed from certain easements, under the system of the equal distribution of profits and losses, as stated in the Viability Report, Article 11, of the $L_{3} R$ and, finally, measures that increase the management capacity of potential subjects authorized to intervene (Articles 15 to 17 of the aforementioned $L_{3} R$ ). All of these are very positive, but their implementation will be slow. Without the adequate instruments or financial vehicles, seeking and finding funding, as previously stated, will not be possible, precluding the definitive takeoff of this activity sector.

\section{EPILOGUE: WE HAVE THE OPPORTUNITY TO CHANGE THINGS. WE MUS PERSEVERE, TO SEEK AND FIND}

The present time, despite all that remains to be done, does present some positive signs. It seems that the time has come in our country for these kinds of strategies and for a change in the urban model. Europe's repeated reprimands due to the country's delay in the transposition of measures related to energy efficiency in the building sector has led to the approval of some measures favoring building renovation -and all this despite the limited or non-existent role the Spanish authorities that are going to manage the Structural Funds (Ministry of Development and the regional governments) have granted to cities, a situation that should be rectified for this new 2014-202O period-.

Integrated Urban Regeneration is a great opportunity to reform the previous urban model, with a view to equity for all the citizens of our cities and urban centers. At the same time it may effectively stimulate Spanish economic reactivation, which is urgent, as it addresses the various problems identified as priorities by the EU: high energy consumption in buildings, the degradation of urban areas, 
la edificación, degradación de zonas urbanas, desempleo, envejecimiento y dependencia, segregación social e innovación.

La L3R, conjuntamente con las demás normas aprobadas durante el año 2013, y a las que se ha hecho referencia en los epígrafes anteriores, apoya un cambio de modelo en la política de suelo y vivienda que había venido desarrollándose en España a lo largo de muchas décadas, y ha sido muy bien recibida inicialmente por la mayor parte de agentes del sector profesional y por parte de las otras administraciones públicas. Aunque empieza a cundir el escepticismo de todos, debido al retraso en la puesta en práctica (Plan Estatal 2013-2016) o a las inadecuadas, por inaplicables, otras medidas económicas planteadas (Línea ICO, Plan PAREER del IDAE, Proyecto CLIMA) y la falta de reacción de las entidades locales y autonómicas. No está en su agenda.

En el momento actual es el momento de la puesta en práctica y en el desarrollo de legislación urbanística autonómica y por supuesto de la local. Los Ayuntamientos deben centrar sus esfuerzos en los mecanismos de gestión y de simplificación de trámites, y en el apoyo a los primeros pasos del proceso.

Y ambas administraciones, de forma coordinada, en la eliminación de barreras de todo tipo que faciliten las actuaciones de rehabilitación a quienes quieran voluntariamente emprenderlas.

No hay demanda generalizada de actuaciones de rehabilitación, pero tampoco una adecuada oferta, ni publica, ni privada, que en su caso la pudiese satisfacer, con soluciones e instrumentos para colaborar y apoyar esa posible demanda. Tampoco hay instrumentos listos ya para resolver las graves carencias económicas, financieras y de gestión necesarias para satisfacer la posible demanda de las Comunidades de Propietarios.

La sola financiación basada en las subvenciones públicas, muy disminuidas en la actualidad y que en el mejor de los casos puede llegar a costear un 20-25\% del coste total y en los recursos privados de los propietarios, no resulta viable. Sin los adecuados instrumentos o vehículos financieros, a buscar y encontrar, en los que se facilite créditos plazos más largos (10-15 años), a las Comunidades de Propietarios, que hoy no existen, no será posible, el despegue definitivo de este sector de actividad del que tan necesitado está nuestro país, por varias razones (empleo, dependencia energética, innovación, etc.).

Hay que insistir, seguir buscando y encontrar.... En ello nos quedamos. unemployment, aging and dependency, social segregation and innovation.

The $L_{3} R$, together with the rest of the regulations approved in 2013, and mentioned in the previous sections, supports a new model governing the land and dwelling policies implemented in Spain over the course of many decades, and has initially been welcomed by most agents in the professional sector and other public administrations. Skepticism, however, is beginning to spread, due to delays in the implementation of the 20132016 State Plan and to other inadequate (due to their unfeasibility) economic measures presented (ICO Line, Plan PAREER, by IDAE; the CLIMA Project) and to the lack of collaboration by local and regional entities. This is not on their agendas.

Now it is time for the implementation and the development of regional and, of course, local, urban planning legislation. City governments must focus their efforts on management mechanisms, streamlining paperwork and supporting the very first steps in the process. And both administrations should coordinate and cooperate to remove all obstacles, facilitating renovation interventions by whomever will voluntarily undertake them.

There is no widespread demand for renovation projects, but neither is there adequate supply (public or private) that could satisfy potential demand through the right solutions and instruments to cooperate in fomenting and filling that demand. Nor are there instruments in place to remedy the great economic, financial and management deficiencies necessary to respond to potential demand by owners' associations.

Funding based only on public subsidies, currently very limited, can cover at most $20-25 \%$ of the total amount. And the private resources of owners are not sufficient. Without adequate instruments or financial vehicles extending ${ }^{1}$ long-term funding (10-15 years) to owners' associations the decisive takeoff of this much-needed activity will not be possible, for several reasons: unemployment, energy dependency, innovation, etc.

We must persevere, keep seeking and finding... and, by doing so, we will evolve.

\section{REFERENCIAS / REFERENCES}

(1) Rubio, J. (2011), Rehabilitación Urbana en España (1989-2010).Barreras actuales y sugerencias para su eliminación, Informes de la Construcción, 63(EXTRA), 5-20, doi: http://dx.doi.org/10.3989/ic.11.060.

(2) Rubio, J. (2013), La rehabilitación integral de algunos conjuntos urbanos de Zaragoza. Una oportunidad para el reciclado de la ciudad. En En Tejedor Bielsa, J. (Ed.), Rehabilitación y regeneración urbana en España. Situación actual y perspectivas. Monografías de la Revista aragonesa de Administración Pública, XV: 237-282.

(3) Parkinson, M. (2014), Regeneración Urbana Integrada en 2014: nada nuevo bajo el sol y que pasa con España. En Menéndez, A. (Coord.), Por la rehabilitación, la regeneración y la renovación urbanas, Número monográfico de Ciudad y Territorio. Estudios territoriales, 2014(179): 11-27.

(4) Kleva, M. (2013), Informe sobre la aplicación y el impacto de las medidas de eficiencia energética en el marco de la política de cohesión (2013/2038(INI)), Comisión de Desarrollo Regional, Presentado al Parlamento europeo en la sesión del 17/07/2013.

(5) de la Cruz Mera, Á. (2014), La ley 8/2013 de 26 de junio, de rehabilitación, regeneración y renovación urbanas. En Menéndez, A. (Coord.), Por la rehabilitación, la regeneración y la renovación urbanas, Número monográfico de Ciudad y Territorio. Estudios territoriales, 2014(179): 29-40. 
(6) Vegara, A., de las Rivas, J.L. (2004), Territorios Inteligentes, p. 156, Madrid: Fundación Metrópoli.

(7) Ponce, J. (2013), Políticas públicas para afrontar la regeneración urbana de barrios degradados. Una visión integrada desde el Derecho. Revista Aragonesa de Administración Pública, 2013(41-42): 11-70.

(8) Hermant-de Callatay, C., Svanfeldt, C. (2011). Ciudades del Mañana. Retos, visiones y caminos a seguir, Comisión Europea, Dirección General de Política Regional. http://ec.europa.eu/regional_policy/sources/docgener/studies/pdf/ citiesoftomorrow/citiesoftomorrow_final_es.pdf.

(9) Ruiz, L. G., Rubio, J. (2006). Estudio y propuestas de rehabilitación de 21 Conjuntos Urbanos. Nuevas propuestas de rehabilitación urbana en Zaragoza. Zaragoza: Sociedad Municipal de Rehabilitación Urbana de Zaragoza.

(10) Hernández Aja, A. (2010). Análisis urbanístico de Barrios Vulnerables en España. Sobre la Vulnerabilidad Urbana. España: Instituto Juan de Herrera, Ministerio de Fomento. http://www.fomento.gob.es/NR/rdonlyres/C88DB66D8669-497C-BEE4-442AE027E2FB/111287/SOBRE_vulnerabilidad.pdf. 